\title{
EFEKTIVITAS PERAN HUBUNGAN INDUSTRIAL PADA PERUSAHAAN GO PUBLIC DITINJAU DARI UU NOMOR 13 TAHUN 2003 TENTANG KETENAGAKERJAAN
}

\author{
Dwi Atmoko \\ Fakultas Hukum, Universitas Bhayangkara Jakarta Raya \\ Email: dwi.atmoko1976@gmail.com
}

Diterima : 13 Nop 2020 | Direvisi : 29 Nop 2020 | Disetujui : 30 Nop 2020| Diterbitkan : 14 Des 2020

\begin{abstract}
The development of the industrial world which is increasingly advanced has made the dynamics of the world of work more dynamic. Many companies, especially companies engaged in industry, as well as banks are taking steps or actions to increase their profits. Technological sophistication leads to a significant reduction in human resources, due to technology transfer taking on human work functions. In principle, the working relationship between the employer and the worker is in a mutually beneficial position where the work party gets profit and the worker gets deep welfare, the meaning here is a symbiotic relationship of mutualism, but there are times for some reason the company takes actions that result in losses to workers. The factors that cause disputes between the company and the workers can be caused by various factors, so this is where the role of industrial relations needs to be effective. The role of industrial relations has a very important role in overcoming all problems. As regulated in Law Number 13 of 2003 concerning manpower, it is regulated regarding disputes between the company and workers. In a more detailed implementation, the Industrial Relations dispute settlement itself is regulated in Law Number 2 of 2004 concerning the Settlement of Industrial Relations Disputes. In fact, an effective settlement which means the word "win-win solution" can be obtained if the employer, in this case the Go Public company, can put in place or manage the company system, especially in its management strategy it is able to manage assets with existing resources, especially where publicly listed companies, which in fact are the majority in Indonesia, are state companies. There are several types of strategies carried out by Go Public companies in order to maintain their business and the resources of their workers, among others, through: Merger, Consolidation, Acquisition and Separation. These strategies are carried out for the running of the company, as well as a way to streamline management and suppress expenditure costs as efficiently as possible. The role of labor protection in the framework of industrial relations can be carried out by workers through the Workers' Union which is a form of representation of workers in the company. Simple aspirations can be conveyed in a bipartite form between the workers and the company in achieving and accommodating workers' demands by harmonizing company conditions so that what is desired between the two parties can be achieved while creating a harmonious relationship between the company and the workers, in order to minimizing the level of disputes that will arise in the future.
\end{abstract}

Keywords: Effectiveness, industrial relations, Go Public Companies 


\begin{abstract}
ABSTRAK
Perkembangan dunia Industri yang semakin maju menbuat dinamika dunia kerja semakin dinamis.Banyak perusahaan-perusahaan , terutama perusahaan yang bergerak di bidang Industri, maupun perbankan mengambil langkah maupun tindakan guna meningkatkan profitnya. Kecanggihan teknologi menimbulkan pengurangan sumber daya manusia dalam tingkat yang signifikan, dikarenakan alih teknologi mengambil fungsi kerja manusia. Pada prinsipnya hubungan kerja antara pihak pengusaha dan pihak pelkerja dalam posisi yang samsama menguntungkan dimana pihak kerja mendapatkan profit dan pihak pekerja mendapatkan kesejahteraan dalam, arti disini adalah hubungan simbiosis mutualisme, akan tetapi ada kalanya karena suatu sebab tertentu pihak perusahaan mengambil tindakan yang mengakibatkan kerugian pada pekerja. Faktor penyebab adanya perselisihan antara pihak perusahaan dan pihak pelerja bisa disebabkan oleh berbagai faktor, sehingga disinilah peran hubungan industrial perlu di efektifkan . Peran hubungan industrial mempunyai peran yang sangat penting dalam mengatasi segala persoalan. Sebagaimana diatur dala Undang-undang Nomor 13 Tahun 2003 Tentang ketenagakerjaan diatur mengenai perselisihan antara pihak perusahaan dan pekerja. Dalam implentasi lebih detail untuk perselesian perselisihan Hubungan Industrial itu sendiri diatur dalam Undang-Undang Nomor 2 Tahun 2004 tentang Penyelesaian Perselisihan Hubungan Industrial. Sebenarnya penyelesaian secara efektif yang dalam arti kata "win-win solution" dapat diperoleh jika pihak pemberi kerja dalam hal ini perusahaan Go Public bisa menempatkan dengan baik atau mengatur sistem perusahaan, terutama dalam strategi managemennya mampu mengatur asset dengan sumber daya yang ada, terutama dimana perusahaan go public yang notabene adalah mayoritas di Indonesia ini adalah perusahaan negara. Ada beberapa jenis strategi yang dilakukan perusahaan Go Public dalam rangka memepertahankan usahanya dan sumber daya para pekerjanya antara lain melalui : Penggabungan, Peleburan,Pengambil alihan dan Pemisahan..Bentuk-bentuk strategi tersebut dilakukan demi berjalannya roda perusahaan, sekaligus sebagai cara merampingkan management dan menekan biaya pengeluaran seefesien mungkin.. Peran perlindungan tenaga dalam rangka hubungan industrial bisa dilakukan pekerja melalui Serikat Pekerja yang dimana sebagai bentuk perwakilan pekerja di dalam perusahaan. Penyampaian aspirasi yang yang sederhana bisa dilakukan dalam bentuk bipartit antara pihak pekerja dan pihak perusahaan dalam mencapai serta mengakomodir permintaan pekerja dengan menyelaraskan kondisi perusahaan sehingga apa yang diinginkan antara kedua belah pihak dapat tercapai sekaligus menciptakan hubungan yang harmonis antara pihak perusahaan dan pihak pekerja, dalam rangka meminimkan tingkat perselisihan yang akan timbul di kemudian hari
\end{abstract}

Kata Kunci: Efektivitas, hubungan industrial, Perusahaan Go Public

\title{
PENDAHULUAN
}

Perkembangan dinamika ketenagakerjaan di Indonesia mengalami perkembangan yang cukup maju. Keberadaan perusahaan-perusahaan. baik itu perusahaan dalam negeri, perusahaan asing, maupun perusahaan milik Negara. Kemudian ada juga beberapa perusahaan yang sudah berubah menjadi perusahaan Go Public. Keberadaan pengusaha dan pekerja merupakan hal sangat krusial dimana pengusaha membutuhkan pekerja dalam usahanya, begitu juga pekerja sangat tergantung pada perusahaan dalam memenuhi kebutuhan hidupnnya. Selanjynya untuk menakomodir hak dan kewajiban antara pengusaha dan pekerja maka diterbitkan perturan yang mengatur tentang itu yaitu Undang-undang Nomor 13 Tahun 2003 tentang Ketenagakerjaan.

Selanjutnya UU No. 13 Tahun 2003 mengatur aturan main antara pihak pengusaha dan pihak pekerja terkait perselisihan yang timbul diantara mereka dalam mencari solusi yang pasti diantara para pihak yang bersengketa. Kemudian dalam pengaturannya juga untuk hubungan industrial itu sendiri juga diatur dalam Undang- 
Undang Nomor 2 Tahun 2004 Tenntang Penyelesaian Perselisihan hubungan Industrial. Disini dapat disampaikan bahwa hubungan antara pihak pengusaha maupun pekerja harus sama-sama mengutamakan keselarasan dalam pekerjaan guna mendapatkan hasil yang diinginkan dimana pengusaha mendapatkan profit atau keuntungan sedangkan pihak pekerja mendapatkan kesejahteraan dan jaminan hidup yang layak.

Dinamika perkembangan serta kemajuan perusahaan sangat dipengaruhi oleh factor internal dan factor eksternal, sehingga kadang perusahaan bias memberikan profit kepada para pekerjanya maupun bisa melakukan tindakan taktis lainnya seperti pemngurangan karyawan, penurunan bonus dan lainnya. Tindakan perusahaan yang tanpa memperhitungkan factor kesejahteraan pekerja karena focus kepada profit dan modal perusahaan dan disinilah timbul permasalahan, sehingga dapat dkemukakan permasalahan disini adalah bagaimana efektivitas peran hubungan industrial pada perusahaan Go Public ditinjau dari UU No.13 tahun 2003 Tentang Ketenagakerjaan? Sejauh mana peran perlindungan tenaga kerja, terutama pada perusahaan Go Public ?

\section{PEMBAHASAN}

\section{Pengertian Hubungan Kerja dan Hubungan Industrial}

Menurut pasal 1 angka 15 Undang-undang No. 13 Tahun 2003 tentang ketenagakerjaan dinyatakan bahwa hubungan kerja adalah hubungan antara pengusaha dengan pekerja/buruh berdasarkan perjanjian kerja, yang mempunyai unsur pekerjaan, upah, dan perintah. Hubungan kerja menurut Imam Soepomo adalah suatu hubungan antara seorang buruh dan seorang majikan, dimana hubugan kerja itu terjadi setelah adanya perjanjian antara kedua belah pihak. Mereka terikat dalam suatu perjanjian, di satu pihak pekerja/buruh bersedia bekerja dengan menerima upah dan pengusaha mempekerjakan pekerja/buruh dengan memberi upah. ${ }^{1}$

Lalu Husni menyebutkan bahwa hubungan kerja adalah hubungan antara buruh dan majikan setelah adanya perjanjian kerja, yaitu suatu perjanjian dimana pihak buruh mengikatkan dirinya pada pihak majikan untuk bekerja dengan mendapatkan upah dan majikan menyatakan kesanggupannya untuk memperkerjakan si buruh dengan membayar upah. ${ }^{2}$ Berbeda dengan hubungan kerja yang hanya melibatkan pengusahadengan pekerja/buruh, hubungan industrial tidak hanya sekeda rmanajemen organisasi perusahaan yang dijalankan oleh seorang manager,yang menempatkan pekerja sebagai pihak yang selalu dapat diatur. Namun, hubungan industrial meliputi fenomena baik di dalam maupun diluar tempat kerja yang berkaitan dengan penempatan dan pengaturan hubungan kerja.

Hubungan industrial menurut Undang-undang No.13 Tahun 2003 tentang Ketenagakerjaan adalah suatu sistem hubungan yang terbentuk antara pelaku usaha dalam proses produksi barang dan jasa yang terdiri dari unsur pengusaha, pekerja/buruh, dan pemerintah yang didasarkan pada nilai-nilai Pancasila dan Undangundang Dasar Negara Republik Indonesia Tahun 1945. Berdasarkan Pedoman Pelaksanaan Hubungan Industrial Pancasila (HIP) dari Departemen Tenaga Kerja pengertian HIP adalah suatu sistem yang terbentuk antara pelaku dalam proses produksi barang dan jasa (pekerja, pengusaha, dan pemerintah) yang didasarkan atas

\footnotetext{
${ }^{1}$ Iman Soepomo dalam Siti Hajati Hoesin. Azas-azas Hukum Perburuhan, Raja Grasindo Persada, Jakarta, 2014, hlm. 54

2 Lalu Husni. Penyelesaian Perselisihan Hubungan Industrial Melalui Pengadilan \& di Luar Pengadilan, Rajawali Pers, Jakarta, 2005, hlm. 51
} 
nilai-nilai Pancasila dan Undang-undang Dasar Negara RI Tahun 1945, yang tumbuh dan berkembang di atas kepribadian bangsa dan kebudayaan nasional Indonesia.

\section{Para Pihak Dalam Hubungan Industrial}

Para pihak dalam pelaksanaan hubungan industrial terdiri atas ${ }^{3}$ :

a. Pemerintah, adalah menetapkan kebijakan, memberikan pelayanan, melaksanakan pengawasan, dan melakukan penindakan terhadap pelanggaran peraturan perundang-undangan ketenagakerjaan;

b. Pekerja/buruh dan serikat pekerja/buruh adalah menjalankan pekerjaan sesuai dengan kewajibanya, menjaga ketertiban demi kelangsungan produksi, menyalurkan aspirasi secara demokratis, mengembangkan perusahaan dan memperjuangkan kesejahteraan anggota beserta keluarganya;

c. Pengusaha dan organisasi pengusaha adalah menciptakan kemitraan, mengembangkan usaha, memperluas lapangan kerja, dan memberikan kesejahteraan pekerja/buruh secara terbuka, demokratis, dan berkeadilan.

\section{Sarana Pendukung Hubungan Industrial}

Menurut Abdul Khakim untuk mengimplementasikan konsep hubungan industrial diperlukan beberapa sarana kelembagaan yaitu :
a. serikat pekerja/serikat buruh;
b. organisasi pengusaha;
c. lembaga kerja sama biparpit (disingkat LKS biparpit);
d. lembaga kerja sama tripartit (disingkat LKS Triparpit);
e. peraturan perusahaan;
f. perjanjian kerja bersama (disingkat $\mathrm{PKB}$ );
g. peraturan Perundang-undangan ketenagakerjaan;
h. lembaga penyelesaian perselisihan hubungan industrial

\section{Perselisihan Hubungan Industrial}

Perselisihan hubungan industrial dapat pula disebabkan oleh pemutusan hubungan kerja. Hal ini terjadi karena hubungan antara pekerja/buruh dan pengusaha merupakan hubungan yang didasari oleh kesepakatan para pihak untuk mengikatkan diri dalam hubungan kerja. Berdasarkan ketentuan Pasal 2 Undang-undang No. 2 Tahun 2004, jenis perselisihan hubungan industrial meliputi:

\subsection{Perselisihan Hak}

Adalah perselisihan yang timbul akibat tidak dipenuhinya hak, akibat adanya perbedaan pelaksanaan atau penafsiran terhadap ketentuan peraturan perundang-undangan, perjanjian kerja, peraturan perusahaan atau perjanjian bersama.

1.2. Perselisihan Kepentingan

Adalah perselisihan yang timbul dalam hubungan kerja karena tidak adanya kesesuaian pendapat mengenai pembuatan dan atau perubahan syarat-syarat kerja yang tidak ditetapkan dalam perjanjian kerja atau peraturan perusahaan atau perjanjian kerja bersama.

\subsection{Perselisihan Pemutusan Hubungan Kerja}

Adalah perselisihan yang timbul karena tidak adanya kesesuaian pendapat mengenai pengakhiran hubungan kerja yang dilakukan oleh salah satu pihak.

\subsection{Perselisihan antar Serikat Pekerja/Serikat Buruh}

\footnotetext{
${ }^{3}$ Abdul Khakim. Dasar-Dasar Hukum Ketenagakerjaan, Citra Aditya Bakti, Bandung, 2014, hlm. 39
} 
Adalah perselisihan antara serikat pekerja/serikat buruh dengan serikat pekerja/serikat buruh lain dalam satu perusahaaan, karena tidak adanya persesuaian paham mengenai keanggotaan, pelaksanaan hak dan kewajiban serikat pekerja. Dengan demikian hak hak yang diatur dalam Undang-undang merupakan hak normatif yaitu, hak yang telah ditetapkan dalam perjanjian dan/atau peraturan perundang-undangan ketenagakerjaan. Perselisihan itu dapat terjadi karena kelalaian atau akibat adanya perbedaan pelaksanaaan atau penafsiran, atau ketidakpatutan salah satu pihak, atau para pihak dalam melaksanakan ketentuan normative tidak mengindahkan apa yang telah diatur dalam peraturan perundang-undangan atau perjanjian (penjelasan Pasal 145 Undang-undang No.13 Tahun 2003).

\section{Perlindungan Hukum Terhadap Tenaga Kerja}

\section{Perlindungan Hukum}

Perlindungan hukum bisa berarti perlindungan yang diberikan terhadap hukum agar tidak ditafsirkan berbeda dan tidak dicederai oleh aparat penegak hukum dan juga bisa berarti perlindungan yang diberikan oleh hukum terhadap sesuatu. Perlindungan hukum juga dapat menimbulkan pertanyaan yang kemudian meragukan keberadaan hukum. Hukum sejatinya harus memberikan perlindungan terhadap semua pihak sesuai dengan status hukumnya karena setiap orang memiliki kedudukan yang sama dihadapan hukum. Setiap aparat penegak hukum jelas wajib menegakkan hukum dan dengan berfungsinya aturan hukum, maka secara tidak langsung pula hukum akan memberikan perlindungan terhadap setiap hubungan hukum atau segala aspek dalam kehidupan masyarakat yang diatur oleh hukum itu sendiri.

\section{Teori Perlindungan Hukum}

Menurut Fitzgerald, Teori perlindungan hukum Salmond bahwa hukum bertujuan mengintegrasikan dam mengkoordinasikan berbagai kepentingan dalam masyrakat karena dalam suatu lalulintas kepentingan, perlindunagn terhadap kepentingan tertentu dapat dilakukan dengan cara membatai berbagai kepentingan di lain pihak. ${ }^{4}$ Kepentingan hukum adalah mengurusi hak dan kepentingan manusia, sehingga hukum memiliki otoritas tertinggi untuk menentukan kepentingan manusia yang perlu diatur dan dilindungi. ${ }^{5}$

Perlindungan hukum harus melihat tahapan yakni perlindungan hukum lahir dari suatu ketentuan hukum dan segala peraturan hukum yang diberikan oleh masyarakat yang pada dasarnya merupkan kesepakatan masyarakat tersebut untuk mengatur hubungan prilaku antara angota-anggota masyarakat dan antara perseorangan dengan pemerintah yang dianggap mewakili kepentingan masyarakat.

Menurut Pjillipus M. Hadjon bahwa perlindungan hukum bagi rakyat sebagai tindakan pemerintah yang bersifat preventif dan respresif. ${ }^{6}$ Perlindungan Hukum yang preventif bertujuan untuk mencegah terjadinya sengketa, yang mengarahkan tindakan pemerintah bersikap hati-hati dalam pengambilan keputusan berdasarkandiskresi dan perlindungan yang resprensif bertujuan untuk mencegah terjadinya sengketa, termasuk penanganannya di lembaga peradilan. ${ }^{7}$ Menurut Satijipto Raharjo, Perlindungan hukum adalah memberikan pengayoman terhadap hak asasi manusia (HAM) yang

\footnotetext{
${ }^{4}$ Satijipto Raharjo, Ilmu Hukum, Citra Aditya Bakti, Bandung, 2000, hlm 53.

${ }^{5}$ Ibid, hlm. 69

${ }^{6}$ Pjillipus M. Hadjon, Perlindungan Hukum bagi Rakyat Indonesia, Bina Ilmu, Surabaya, 1987, hlm 2.

${ }^{7}$ Maria Alfons, Implentasi Perlindungan Indikasi Geografis Atas Produk-Produk Masyarakat Lokal Dalam Prespektif Hak kekayaan Intelektual, Universitas Brawijaya, Malang, 2010, hlm.18
} 
dirugikan orang lain dan perlindungan itu diberikan kepada masyarakat agar dapat menikmati semua hak-hak yang diberikan oleh hukum ${ }^{8}$

Menurut Lili Rasjidi dan I.B Wysa Putra bahwa hukum dapat didifungsikan untuk menghujudkan perlindungan yang sifatnya tidak sekedar adaptif dan fleksibel, melaikan juga predektif dan antipatif. ${ }^{9}$ Perlindungan hukum merupakan gambaran dari bekerjanya fungsi hukum untuk mewujudkan tujuan-tujuan hukum, yakni keadilan, kemanfaatan dan kepastian hukum.Perlindungan hukum adalah suatu perlindungan yang diberikan kepada subyek hukum sesuai dengan aturan hukum, baik itu yang bersifat preventif maupun dalam bentuk yang bersifat represif, baik yang secara tertulis maupun tidak tertulis dalam rangka menegakkan peraturan hukum.Hakekatnya setiap orang berhak mendapatkan perlindungan dari hukum.Hampir seluruh hubungan hukum harus mendapat perlindungan dari hukum.Oleh karena itu terdapat banyak macam perlindungan hukum.

Selama ini pengaturan perlindungan korban belum menampakkan pola yang jelas, dalam hukum pidana positif yang berlaku pada saat ini perlindungan korban lebih banyak merupakan "perlindungan abstrak" atau "perlindungan tidak langsung". Artinya berbagai rumusan tindak pidana dalam peraturan perundang-undangan selama ini pada hakekatnya telah ada perlindungan in abstracto secara langsung terhadap kepentingan hukum dan hak asasi korban. ${ }^{10}$

Perlindungan secara tidak langsung dalam peraturan hukum positif tersebut belum mampu memberikan perlindungan secara maksimal.Karena realitas di Indonesiamenunjukkan bahwa hukum yang berlaku secara pasti belum mampu menjamin kepastian dan rasa keadilan.

\section{Penyebab Tenaga Kerja Terkena PHK}

a. Pemutusan Hubungan Kerja oleh Perusahaan

Salah satu penyebab terjadinya pemutusan hubungan kerja (PHK) adalah karena alasan efisiensi. PHK dengan alasan efisiensi diatur secara rinci dan jelas dalam UndangUndang No.13 Tahun 2003 dalam Pasal 164 ayat (3) yang menyatakan: " Pengusaha dapat melakukan pemutusan hubungan kerja terhadap pekerja/buruh karena perusahaan tutup bukan karena mengalami kerugian 2 (dua) tahun berturut-turut atau bukan karena keadaan memaksa (force majeur) tetapi perusahaan melakukan efisiensi, dengan ketentuan pekerja/buruh berhak atas uang pesangon sebesar 2 (dua) kali ketentuan Pasal 156 ayat (2), uang penghargaan masa kerja sebesar 1 (satu) kali ketentuan Pasal 156 ayat (3) dan uang penggantian hak sesuai ketentuan Pasal 156 ayat (4)."

Banyak pihak yang menafsirkan bahwa salah satu alasan yang dapat digunakan perusahaan untuk melakukan PHK terhadap pekerjanya adalah karena "melakukan efisiensi”. Padahal, sebenarnya Undang-Undang Ketenagakerjaan sendiri tidak pernah mengenal alasan PHK karena melakukan efisiensi.Kesalahan penafsiran tersebut mungkin terjadi karena banyak pihak yang kurang cermat membaca redaksional pada ketentuan yang ada (hanya sepenggal-sepenggal). ${ }^{11}$ Dengan kondisi ini sering sekali dijadikan celah oleh pihak perusahaan untuk menghilangkan hak warga negara untuk bekerja sebagaimana dijamin Pasal 28D ayat (2) UUD Negara RI Tahun 1945. Sebab,

\footnotetext{
${ }^{8}$ Satjipto Raharjo, Op.cit. hlm. 54

${ }^{9}$ Lili Rasjidi dan I.B Wysa Putra ,Hukum Sebagai Suatu Sistem, Remaja Rosdakarya, Bandung, 1993, hlm 118.

${ }^{10}$ Barda Nawawi Arief, Perlindungan Korban Kejahatan Dalam Proses Peradilan Pidana, Jurnal Hukum Pidana Dan Kriminologi, Vol. I/No.I/1998, hlm 16-17.

${ }^{11} \mathrm{http}: / /$ boedexx.blogspot.com/2009/08/phk-karena-wfisiensi.html
} 
pekerja dapat setiap saat di-PHK dengan dalih efisiensi meski tanpa kesalahan dan kondisi perusahaan dalam keadaan baik sekalipun."Karena itu, Pasal 164 ayat (3) inkonstitusional." 12

Tanggapan lain menyatakan bahwa tujuan perusahaan melakukan PHK dengan alasan efisiensi dilatarbelakangi oleh tujuan untung mengurangi beban perusahaan supaya dapat tetap beroperasi. Alasan-alasan lainnya seperti dalam kondisi krisis global yang mengharuskan pengurangan pekerja, pengusaha tidak perlu khawatir melakukan PHK karena efisiensi sebab ada alasan hukum pasal 164 ayat (3) UndangUndang No. 13 Tahun 2003.

Mengenai PHK itu sendiri secara khusus juga diatur dalam UU PPHI Dengan berlakukan UU PPHI tersebut, Undang-Undang Nomor 12 Tahun 1964 tentang Pemutusan Hubungan Kerja di Perusahaan Swasta dan Undang-undang Nomor 22 Tahun 1957 tentang Penyelesaian Perselisihan Perburuhan (P3) dinyatakan tidak berlaku lagi. Namun, untuk peraturan pelaksanaan kedua undang-undang tersebut masih tetap berlaku sepanjang tidak bertentangan dengan UU PPHI. ${ }^{13}$

Pada umumnya kelangsungan ikatan kerja bersama antara perusahaan dengan tenaga kerja terjalin apabila kedua belah pihak masih saling membutuhkan dan saling patuh dan taat akan perjanjian yang telah disepakatinya pada saat mereka mulai menjalin kerja bersama. Dengan adanya keterikatan bersama antara para tenaga kerja berarti masing-masing pihak memiliki hak dan kewajiban. Demikian pula sebaliknya, apablia terjadi PHK berarti manajer tenaga kerja dituntut untuk memenuhi hak dan kewajiban terhadap tenaga kerja sesuai dengan kondisi pada saat terjadi kontrak kerja. ${ }^{14}$

Bagi setiap pekerja/buruh, pengakhiran atau PHK bisa sejauh mimpi buruk. Setiap pekerja/buruh sedapat mungin mengupayakan agar dirinya tidak sampai kehilangan pekerjaan.PHK dapat berarti awal dari sebuah penderitaan.Namun demikian, suka atau tidak suka, pengakhiran hubungan kerja sesungguhnya adalah sesuatu yang cukup dekat dan sangat mungkin serta wajarterjadi dalam konteks hubungan kerja, hubungan antara majikan (pengusaha) dengan pekerja/buruh.

Seseorang pengusaha dalam mengembangkan usahanya selalu berkeinginan agar perusahaan yang dimlikinya dapat berjalan dengan baik dan sukses, hal ini bdapat terlaksana apabila produksi barang-barang yang dihasilkan dapat diminati dan laku terjual di pasaran dengan harga relatif murah dan kualitas baik. Salah satu keberhasilan yang didapat adalah adanya kerjasama yang baik antara pengusaha dengan pekerja/buruh. Kondisi demikian tidak mudah terlaksana terus-menerus karena setiap pekerja/buruh ada yang patuh dan taat pada pemimpin dan ada juga yang tidak mematuhi perintah yang diberikan. Setiap orang mempunyai tujuan dan motivasi yang berbeda dalam melakukan pekerjaan. Bagi mereka yang tidak patuh atau menentang perusahaan dapat diberikan teguran atau sanksi balikan yang lebih tegas diputuskn hubungan kerjanya. Secara yuridis dalam Undang-undang Nomor 13 Tahun 2003, PHK oleh perusahaan disebabkan oleh :

1. Perusahaan mengalami kemunduran sehingga perlu rasionalisasi atau pengurangan jumlah pekerja/buruh. Dalam hal PHK dengan alasan rasionalisasi atau kesalahan ringan pekerja/buruh dalam Undang-undanhg Nomor 13 Tahun 2003 Pasal 151 ayat (1) ditentukan bahwa pengusaha,

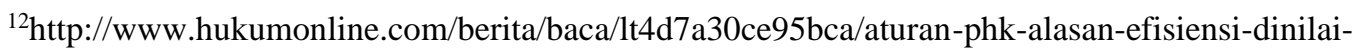
inkonstitusional-

${ }^{13} \mathrm{http}$ ://requestartikel.com/pengertian-dan-pengaturan-pemutusan-hubungan-kerja 201104 727. html,

${ }^{14}$ B. Siswanto Sastrohadiwiryo, Manajemen Tenaga kerja Indonesia, Pendekatan Administratif dan Operasional, PT. Bumi Aksara, Jakarta, 2005, hlm.1
} 
pekerja/buruh, serikat pekerja/buruh dan pemerintah, berupaya mengusahakan agar tidak terjadi PHK. Dalam hal, upaya tersebut telah dilakukan, tetapi PHK tidak dapat dihindari, maka maksud PHK wajib dirundingkan oleh pegusaha dan SP/SB atau dengan pekerja/buruh yang bersangkutan tidak menjadi anggota SP/SB.

2. Pekerja/buruh telah melakukan kesalahan, baik kesalahan yang melanggar ketentuan yang tercantum dalam peraturan perusahaan, perjanjian kerja atau PKB (kesalahan ringan), maupun kesalahan pidana (kesalahan berat). Pekerja/buruh yang diputus hubungan kerjanya karena alasan telah melakukan kesalahan berat hanya dapat memperoleh uang pengganti hak.

Pemutusan Hubungan Kerja dengan alasan rasionalisasi atau kesakahan ringan pekerja/buruh dalam undang-undang Nomor 13 Tahun 2003 dalam Pasal 151 ayat 1 ditentukan bahwa pengusaha, pekerja/buruh, serikat pekerja/buruh dan pemerintah dengan segala upaya harus megusahakan agar jangan terjadi PHK. Apabila upaya tersebut telah dilakukan, tetapi PHK tidak dapat dihindari, maka maksud PHK wajib dirundingkan oleh pengusaha dan serikat pekerja/serikat buruh atau dengan pekerja/buruh yang bersangkutan tidak menjadi anggota serikat pekerja/serikat buruh.

Apabila perundingan benar-benar tidak menghasilkan persetujuan, pengusaha hanya dapat memutuskan hubungan kerja dengan pekerja/buruh setelah memperoleh penetapan dari lembaga PPHI yang dalam UU PPHI. Permohonan penetapan PHK diajuakn secara tertulis kepada PHI disertai dengan alasan yang menjadi dasarnya. Permohonan tersebut akan diterima apabila rencana PHK tersebut dirundingkan oleh pengusaha dan serikatpekerja/serikat buruh atau dengan pekerja/buruh, apabila pekerja/buruh yang bersangkutan tidak menjadi anggota serikat pekerja/serikat buruh. Selama putusan PHI belum ditetapkan, baik penugsaha maupun pekerja/buruh harus tetap melaksanakan segala kewajibannya, atau pengusaha dapat melakukan tindakan skorsing kepada pekerja/buruh yang sedang dalam proses PHK dengan tetap wajib membayar upah beserta hak-hak lainnya yang biasa diterima pekerja/buruh.

\section{b. Pemutusan Hubungan Kerja karena Pekerja/Buruh}

Pekerja/buruh sebagai manusia merdeka berhak memutuskan hubungan kerja dengan cara mengundurkan diri atas kemauan sendiri. Kehendak untuk mengundurkan diri ini dilakukan tana penetapan oleh Lembaga Penyelesaian Perselisihan Hubungan Industrial. Hak untuk mengundurkan diri melekat pada setiap pekerja/buruh karena pekerja/buruh tidak boleh dipaksa untuk bekerja bila tiba ia sendiri tidak menghendakinya. Pekerja/buruh berhak untuk memutuskan hubungan kerja dengan pihak pengusaha, karena pada prinsipnya pekerja/buruh tidak boleh dipaksa untuk terus-menerus bekerjasama apabila ia sendiri tidak menghendakinya. Dengan demikian PHK oleh pekerja /buruh ini,yang aktif untuk meminta diputuskan hubungan kerjanya adalah pekerja/buruh tersebut.

Pekerja/buruh dapat mengajukan permohonan PHK kepada lembaga PPHI,dalam hal pengusaha melakukan perbuatan:

1) Menganiaya, menghina secara kasar atau mengancam pekerja/buruh;

2) Membujuk dan/atau menyuruh pekerja/buruh untuk melakukan perbuatan yang bertemtangan dengan peraturan perundang-undangan;

3) Tidak membayar upah tepat waktu yang telah ditentukan selama 3 (tiga) bulan berturut-turut atau lebih;

4) Tidak melakukan kewajiban yang telah di janjikan kepada pekerja/buruh; 
5) Memerintahkan pekerja/buruh untuk melaksanakan pekerjaan diluar yang diperjanjikan; atau

6) Memberikan pekerjaan yang membahayakna jiwa, keselamatan, kesehatan atau kesusilaan pekerja/buruh, sedangkan pekerjaan tersebut tidak dicantumkan pada perjanjian kerja.

Pekerja/buruh dapat mengakhiri hubungan kerja dengan melakukan pengunduran diri atas kemauan sendiri tanpa perlu meminta penetapan dari lembaga Penyelesaian Perselisihan Hubungan Industrial, dan kepada pekerja/buruh yang bersangkutan memperoleh uang penggantian hak sesuai ketentuan Pasal 156 Ayat 4. Selain uang penggantian hak, pekerja/buruh diberikan uang pisah yang besar dan pelaksanaannya diatur dalam perjanjian kerja,peraturan perusahaan atau PKB. Pekerja atau buruh yang mengundurkan diri tersebut harus memenuhi syarat:

1) Mengajukan permohonan pengunduran diri secara tertulis selambatlambatnya 30 (tiga puluh) hari sebelum tanggal mulai pengunduran diri;

2) Tidak terikat dalam ikatan dinas; dan

3) Tetap melaksanakan kewajiban sampai tanggal mulai pengunduran diri.

Pekerja/buruh yang mengundurkan diri tersebut berhak atas uang pengganti hak sebagaimana diatur dalam peraturan perundang-undangan.Bagi pekerja/buruh yang tugas dan fungsinya tidak mewakili kepentingan pengusaha secara langsung,selain menerima uang pengganti hak diberikan pula uang pisah yang besar dan pelaksanaannya diatur dalam perjanjian kerja, peraturan perusahaan, atau perjanjian kerja bersama.

\section{Perlindungan Tenaga Kerja di Perusahaan Go Public}

Dalam praktiknya, dinamika hubungan kerja antara pekerja dan perusahaan dapat terjadi karena restrukturisasi perusahaan. Undang-Undang Nomor 40 Tahun 2007 tentang Perseroan Terbatas (selanjutnya disebut UU No. 40 Tahun 2007) mengakomodir restrukturisasi tersebut melalui 4 (empat) cara, yaitu:

1. Penggabungan

Penggabungan yaitu perbuatan hukum yang dilakukan oleh satu perseroan atau lebih untuk menggabungkan diri dengan perseroan lain yang telah ada yang mengakibatkan aktiva dan pasiva dari perseroan yang menggabungkan diri beralih karena hukum kepada Perseroan yang menerima penggabungan dan selanjutnya status badan hukum Perseroan yang menggabungkan diri berakhir karena hukum. Penggabungan perusahaan tersebut dilatarbelakangi oleh beberapa hal seperti keuntungan biaya (cost advantage), penurunan risiko (lower risk), meminimalkan penundaan operasi (fewer operation delays), menghindari pengambilalihan (avoidance of take over), dan perolehan aset tidak berwujud (acquisition intangible assets) ${ }^{15}$

Salah satu contoh penggabungan perusahaan dapat dilihat dari penggabungan beberapa bank untuk menindaklanjuti kebijakan Bank Indonesia yang mengeluarkan single present policy. Penggabungan pada perbankan dilakukan dengan cara penggabungan usaha dua atau lebih bank dengan cara mempertahankan berdirinya salah satu bank dan melikuidasi bank-bank lainnya. Pelaksanaan penggabungan tersebut dapat dilakukan dengan pembelian seluruh saham oleh bank lainnya dengan mengadakan perjanjian penggabungan perusahaan.

2. Peleburan

${ }^{15}$ UndangUndang Nomor 40 Tahun 2007 tentang Perseroan Terbatas 
Peleburan yaitu perbuatan hukum yang dilakukan oleh dua perseroan atau lebih untuk meleburkan diri dengan cara mendirikan satu perseroan baru yang karena hukum memperoleh aktiva dan pasiva dari perseroan yang meleburkan diri dan status badan hukum perseroan yang meleburkan diri berakhir karena hukum.

. Salah satu contohnya adalah PT Bank Mandiri yang merupakan hasil penggabungan 4 (empat) bank yaitu Bank Bumi Daya, Bank Dagang Negara, Bank Pembangunan Indonesia, dan Bank Expor Impor Indonesia. Dalam hal ini, hubungan kerja mengalami perubahan dimana hubungan kerja antara pekerja masing-masing bank beralih kepada PT Bank Mandiri setelah tanggal efektif peleburan.

3. Pengambilalihan

Pengambilalihan yaitu perbuatan hukum yang dilakukan oleh badan hukum atau perseorangan untuk mengambil alih saham perseroan yang mengakibatkan beralihnya pengendalian atas perseroan tersebut.. Dalam hal ini tidak terjadi perubahan hubungan kerja karena perusahaan hanya mengalami perubahan kepemilikan saham saja.

4. Pemisahan

Pemisahan perusahaan dapat dilihat dari berbagai bank yang ada di Indonesia dimana mereka melepaskan unit usaha syariah menjadi bank syariah seperti pemisahan perusahaan diikuti dengan perjanjian pengalihan hubungan kerja yang melibatkan pekerja, perusahaan yang memisahkan diri, dan perusahaan hasil pemisahan, diaman penandatangan perjanjian tersebut dilakukan sebelum tanggal efektif pemisahan yang melibatkan pekerja, perusahaan yang memisahkan diri, maupun perusahaan hasil pemisahan.

Berkaitan dengan restrukturisasi tersebut, UU No. 13 Tahun 2003 memberikan pilihan kepada perusahaan maupun pekerja menentukan kelanjutan hubungan kerja pasca restrukturisasi perusahaan sebagai berikut:

1.5. Perusahaan dapat melakukan pemutusan hubungan kerja terhadap pekerja/buruh dalam hal terjadi perubahan status, penggabungan, peleburan, atau perubahan kepemilikan perusahaan dan pekerja/buruh tidak bersedia melanjutkan hubungan kerja, maka pekerja/buruh berhak atas uang pesangon sebesar 1 (satu) kali sesuai ketentuan Pasal 156 ayat (2), uang pernghargaan masa kerja 1 (satu) kali ketentuan Pasal 156 ayat (3) dan uang penggantian hak sesuai dalam Pasal 156 ayat (4) UU No. 13 tahun 2003.

1.6. Pengusaha dapat melakukan pemutusan hubungan kerja terhadap pekerja/buruh karena perubahan status, penggabungan, peleburan, atau perubahan kepemilikan perusahaan dan pengusaha tidak bersedia menerima pekerja/buruh di perusahaannya, maka pekerja/buruh berhak atas uang pesangon sebesar 2 (dua) kali ketentuan Pasal 156 ayat (2), uang penghargaan masa kerja 1 (satu) kali ketentuan dalam Pasal 156 ayat (3), dan uang penggantian hak sesuai ketentuan Pasal 156 ayat (40 UU No.13 Tahun 2003.

Beberapa contoh kasus di atas menimbulkan perselisihan hubungan industrial seperti:

(1) Perselisihan hak, perselisihan karena tidak dipenuhinya hak akibat perbedaan penafsiran terhadap ketentuan peraturan perundang-undangan, atau perjanjian kerja bersama,

(2) Perselisihan kepentingan adalah perselisihan yang imbul dalam hubungan kerja karena tidak adanya kesesuaian pendapat mengenai pembuatan, dan atau perubahan syarat-syarat kerja yang ditetapkan dalam perjanjian kerja, atau peraturan perusahaan atau perjanjian kerja bersama,

Perselisihan pemutusan hubungan kerja adalah perselisihan yang timbul karena tidak adanya kesesuaian pendapat mengenai pengakhiran hubungan kerja yang dilakukan 
salah satu pihak. Pelanggaran serta memberikan rambu-rambu atau batasan-batasan dalam melakukan suatu kewajiban.

\section{KESIMPULAN}

Peran hubungan industrial mempunyai peran yang sangat penting dalam mengatasi segala persoalan. Sebagaimana diatur dala Undang-undang Nomor 13 Tahun 2003 Tentang ketenagakerjaan diatur mengenai perselisihan antara pihak perusahaan dan pekerja. Dalam implentasi lebih detail untuk perselesian perselisihan Hubungan Industrial itu sendiri diatur dalam Undang-Undang Nomor 2 Tahun 2004 tentang Penyelesaian Perselisihan Hubungan Industrial. Sebenarnya penyelesaian secara efektif yang dalam arti kata " win-win solution" dapat diperoleh jika pihak pemberi kerja dalam hal ini perusahaan Go Public bisa menempatkan dengan baik atau mengatur sistem perusahaan, terutama dalam strategi managemennya mampu mengatur asset dengan sumber daya yang ada, terutama dimana perusahaan go public yang notabene adalah mayoritas di Indonesia ini adalah perusahaan negara. Ada beberapa jenis strategi yang dilakukan perusahaan Go Public dalam rangka memepertahankan usahanya dan sumber daya para pekerjanya antara lain melalui : Penggabungan, Peleburan,Pengambil alihan dan Pemisahan..Bentuk-bentuk strategi tersebut dilakukan demi berjalannya roda perusahaan, sekaligus sebagai cara merampingkan management dan menekan biaya pengeluaran seefesien mungkin.. Peran perlindungan tenaga dalam rangka hubungan industrial bisa dilakukan pekerja melalui Serikat Pekerja yang dimana sebagai bentuk perwakilan pekerja di dalam perusahaan. Penyampaian aspirasi yang yang sederhana bisa dilakukan dalam bentuk bipartit antara pihak pekerja dan pihak perusahaan dalam mencapai serta mengakomodir permintaan pekerja dengan menyelaraskan kondisi perusahaan sehingga apa yang diinginkan antara kedua belah pihak dapat tercapai sekaligus menciptakan hubungan yang harmonis antara pihak perusahaan dan pihak pekerja, dalam rangka meminimkan tingkat perselisihan yang akan timbul di kemudian hari.

\section{DAFTAR PUSTAKA}

Abdul Khakim. 2014. Dasar-Dasar Hukum Ketenagakerjaan Indonesia Cetakan ke-4 Edisi Revisi. Citra Aditya Bakti, Bandung.

Siswanto Sastrohadiwiryo, 2005. Manajemen Tenaga kerja Indonesia, Pendekatan Administratif dan Operasional, Bumi Aksara, Jakarta.

Lalu Husni, 2005. Penyelesaian Perselisihan Hubungan Industrial Melalui Pengadilan \& di Luar Pengadilan. Rajawali Pers, Jakarta.

Lili Rasjidi dan Putra, I.B. Wyasa. 1993. Hukum Sebagai Suatu Sistem, PT.Remaja Rosdakarya, Bandung.

----------. 2003. Hukum Sebagai Suatu Sistem, Mandar Maju, Bandung.

Maria Alfons, 2010. Implentasi Perlindungan Indikasi Geografis Atas Produk-Produk Masyarakat Lokal Dalam Prespektif Hak kekayaan Intelektual. Universitas Brawijaya, Malang. 
Phillipus M. Hadjon, 1987. Perlindungan Hukum bagi Rakyat Indonesia. PT. Bina Ilmu, Surabaya.

\section{Peraturan Perundang-undangan}

Undang-Undang Nomor 22 Tahun 1957 tentang Penyelesaian Perselisihan Perburuhan.

Undang-Undang Nomor 12 Tahun 1964 tentang Pemutusan Hubungan Kerja di Perusahaan Swasta.

Undang-Undang No.13 Tahun 2003 tentang Ketenagakerjaan.

Undang-Undang Nomor 2 Tahun 2004 tentang Penyelesaian Perselisihan Hubungan Industrial.

UndangUndang Nomor 40 Tahun 2007 tentang Perseroan Terbatas

Keputusan Menteri Tenaga Kerja dan Transmigrasi Nomor: KEP-92/MEN/2004.

\section{Jurnal/ Artikel Ilmiah}

Barda Nawawi Arief, Perlindungan Korban Kejahatan Dalam Proses Peradilan Pidana, Jurnal Hukum Pidana Dan Kriminologi, Vol. I/No.I/1998, hlm 16-17.

Raharjo, Satjipto. 1999. "Masalah Kebhinekaan Sosial Budaya Dalam Reformasi Hukum Nasional Menuju Masyarakat Madanih", Makalah, disampaikan pada Seminar Hukum Nasional ke- VII, Diselenggarakan Oleh BPHN-Depkeh RI di Jakarta.

Satjipto Rahardjo, Mengejar Keteraturan Menemukan Ketidakteraturan (TeachingOrder Finding Disorder), Pidato mengakhiri masa jabatan sebagai guru besartetap pada Fakultas Hukum Universitas Diponegoro Semarang, 15 Desember 2000.

\section{Internet}

http://www.hukumonline.com/berita/baca/lt4d7a30ce95bca/aturan-phk-alasanefisiensi-dinilai-inkonstitusional

http://requestartikel.com/pengertian-dan-pengaturan-pemutusan-hubungan-kerja201104727.html

$\underline{\text { www.orintononline.blogspot.com/perdebatanteorihukumfriedman }}$

www.kumpulanartikelhukum.com/perdebatanteorihukumfriedman 